Original article

\title{
EFFECTS OF TRIVALENT AND HEXAVALENT DIETARY CHROMIUM ON BLOOD BIOCHEMICAL PROFILE IN JAPANESE QUAILS
}

\author{
A. ALIJAGIC, E. ISLAMAGIC, M. FOCAK \& D. SULJEVIC \\ Faculty of Science, University of Sarajevo, Sarajevo, Bosnia and Herzegovina
}

\section{Summary}

Alijagic, A., E. Islamagic, M. Focak \& D. Suljevic, 2018. Effects of trivalent and hexavalent dietary chromium on blood biochemical profile in Japanese quails. Bulg. J. Vet. Med., 21, No 4, 470-477.

Trivalent chromium is an essential trace element for humans and animals and it is the final product of hexavalent chromium reduction in the cell. It is an integral part of the glucose-tolerance factor, which increases the systemic impact of insulin. The aim of this study was to analyse the effect of trivalent and hexavalent chromium on selected biochemical parameters in Japanese quails. Birds were divided into three groups: group I (control group, $\mathrm{n}=12$ ), group II (treated with trivalent chromium, $\mathrm{n}=12$ ) and group III (treated with hexavalent chromium, $\mathrm{n}=12$ ). During 20 days of follow-up, control and experimental groups of quails had identical diet; chromium was added daily into the food $(5 \mathrm{mg} / \mathrm{kg})$ and water $(5 \mathrm{mg} / \mathrm{L})$ of the experimental groups. Glucose concentrations were the highest in Group III, while lowest glucose concentrations were obtained in Group I. There were higher differencies regarding blood biochemical parameters between control group and quails treated with $\mathrm{Cr}(\mathrm{VI})$. Our results showed that hexavalent chromium had negative effects on biochemical parameters in quails, while treatment with $\mathrm{Cr}(\mathrm{III})$ showed minor fluctuations in concentrations or activities of blood biochemical parameters.

Key words: biochemical parameters, birds, diet, metals, serum, toxicity

\section{INTRODUCTION}

Extracelular, water-soluble, hexavalent chromium exists in form of chromium oxyanion. The reduction of hexavalent chromium is usually mediated by nonenzymatic reductants, such as: ascorbate (vitamin C), low molecular weight thiols, GSH and cysteine (Shati, 2014). Trivalent chromium is the final product of hexava- lent chromium reduction in the cell (Zhitkovich, 2011).

To date, a lot of useful information related to identification and the positive effect of derivatives of chromium with a different valence was collected. Chromium chloride is most important mineral form of chromium used as a dietary supplement (Uyanik et al., 2002). Large 
number of studies showed that organic chromium in form of chromium picolinate and chromium nicotinate might be used in diets because of their positive influence on reduction of serum glucose and cholesterol concentrations in laying quails (Yildiz et al., 2004). Additionally, inorganic compounds containing trivalent chromium, such as chromium chloride, also, to a lesser extent, had a positive effects on biochemical parameters as well as physiological and anatomical characteristics of the animals and humans (Boudjouk \& Ho So, 2007). Earlier studies showed that $\mathrm{Cr}$ (III) in its inorganic form does not affect the cholesterol concentration in the serum of quails and other experimental animals (Thomas \& Gropper, 1996) as well as in the human serum. Therefore, the World Health Organization recommended limited intake of $\mathrm{Cr}$ (III) as antihyperglycaemic and antihyperlipidaemic agent, with emphasis on the necessity of using organic Cr(III) compounds, due to their harmlessness, higher solubility and lack of its precipitation affinity in the organism. Otherwise, $\mathrm{Cr}(\mathrm{VI})$ and its derivates, showed extremely toxic effect which results in various point mutations in DNA and to chromosomal damage, as well as to oxidative changes in proteins and adducts formation (Dayan \& Paine, 2001).

Alanine aminotransferase (ALAT) and succinate dehydrogenase increased severalfold, especially ALAT, whose serum concentration was elevated up to four times in broiler chickens (Króliczewska et $a l ., 2004)$. The concentration of bile acids was also twice higher regardless of the gender. Results regarding cholesterol concentration were not uniform. A study (Króliczewska et al., 2004) reported decreased cholesterol in broiler chickens along with lower concentration of triglycerides. Concentration of creatine kinase increased twice after chromium application in chickens (Cupo \& Donaldson, 1987). Trivalent chromium is an essential trace element in humans and animals (McDonald et al., 1992). Expressed interest in monitoring the utilisation of chromium supplemented to broiler chickens diet has been shown (Króliczewska et al., 2004). As in the case of triglycerides, studies showed that short-term application of $\mathrm{Cr}(\mathrm{VI})$ (up to a month) decreased the concentration of total proteins in chickens.

The positive effect of chromium on human health is related to fact that chromium is an integral part of the glucosetolerance factor (GTF) that increases the impact of insulin, one of the most important anabolic hormones (Anderson \& Polansky, 1995; Cefalu \& Hu, 2004). GTF consists of one trivalent chromium atom linked with several molecules of niacin (vitamin $\mathrm{B}_{3}$ ) and amino acids found in glutathione (glutamic acid, glycine and cysteine) (Cefalu \& Hu, 2004). However, several studies have investigated the association between chromium valence and its carcinogenicity (Langard, 1990; Zhitkovich, 2011).

Hexavalent chromium passes easily through biological membranes and reacts with proteins and nucleic acids inside the cell, which potentially had negative impact on cell metabolism and concentration of blood biochemical parameters.

The aim of this study was to analyse the effects of trivalent and hexavalent chromium on selected biochemical parameters in Japanese quails (Coturnix japonica Temminck \& Schlegel, 1849) to determine if trivalent chromium as a convenient dietary supplement was safe for use. Also we aimed to evaluate whether hexavalent chromium should be definitely characterised as toxic or should we start to re-consider its pleiotropic effects. 


\section{MATERIALS AND METHODS}

\section{Breeding}

All individuals used in the study were females and they come from a private farm in Vogošća, Bosnia and Herzegovina. Growing of quails was carried out according to standardised procedures and optimal conditions for this species (Randall \& Bolla, 2008). All animals were treated in accordance with the Declaration on the Rights of Animals and Universal Declaration on Animal Welfare.

\section{Experimental design}

Quails used in this experiment were 37 days old. Experimental design included three groups: group I (control group, $\mathrm{n}=12$ ), group II (quails treated with trivalent chromium, $\mathrm{n}=12$ ) and group III (quails treated with hexavalent chromium, $\mathrm{n}=12$ ). All birds had identical diet consisting of corn grits, however chromium supplements were added in food and water to the experimental group of animals $(5 \mathrm{mg}$ of chromium supplements per liter of water and $5 \mathrm{mg}$ per kilogram of food). During the 20 days of chromium treatment, supplementation was repeated daily.

\section{Chromium derivatives}

Chromium (III) chloride $\left(\mathrm{CrCl}_{3}\right)$ is a derivative of trivalent chromium, stable in two forms: hydrated and anhydrous. During the experiment the anhydrous chromium (III) chloride (Semikem, Bosnia and Herzegovina), a solid purple coloured compound was used. Chromium (VI) oxide $\left(\mathrm{CrO}_{3}\right)$ is a derivative of hexavalent chromium, (IUPAC name chromium trioxide). Chromium (VI) oxide (Semikem, Bosnia and Herzegovina) was used during the experiment.

\section{Sampling and biochemical analysis}

Blood samples were collected by jugular vein venipuncture and rapid decapitation. Venipuncture is performed by using a sterile insulin syringe. Collected blood samples were transferred to test tubes without anticoagulants for serum analysis. The next step was centrifugation (Heraeus-Sepatech, Germany) at $2000 \mathrm{rpm}$ for 10 minutes. Analyses of biochemical parameters: triglycerides, cholesterol, proteins, lactate dehydrogenase (LDH), creatine kinase $(\mathrm{CK})$, creatinine and urea were preformed immediately after blood colection and by spectrophotometric metods (Zuzi 4110ED, (Auxilab, Spain). Glucose concentration were measured by using glucometer Accu-Check Code 268 (Roche, Switzerland).

\section{Statistical analysis}

Results were analysed by using SPSS (v. 20; SPSS, Inc., Chicago, IL, SAD) software for estimation: mean values of different biochemical parameters and statistically significant difference in all above mentioned parameters with regard to factors supposed to cause variation. ANOVA was used to test statistical differencies between groups I, II and III. Post hoc multiple tests (Tukey HSD) were also done, for the detection of pairs of groups between which the differences are significant. $\mathrm{P}$ values lower than $0.05(\mathrm{P}<0.05)$ considered significant and $\mathrm{p}$ values lower than $0.01(\mathrm{P}<0.01)$ considered highly significant.

\section{RESULTS}

Values (triglycerides, cholesterol, proteins, creatinine and urea) and activity (lactate dehydrogenase and creatine kina- 
Table 1. Mean \pm SD $(n=12)$ values of observed blood biochemical parameters of Japanese quails

\begin{tabular}{|c|c|c|c|c|}
\hline Parameter & $\begin{array}{c}\text { Group I } \\
(\text { Control, } n=12)\end{array}$ & $\begin{array}{c}\text { Group II } \\
\left(\mathrm{Cr}^{3+}, \mathrm{n}=12\right)\end{array}$ & $\begin{array}{c}\text { Group III } \\
\left(\mathrm{Cr}^{6+}, \mathrm{n}=12\right)\end{array}$ & $\begin{array}{l}\text { Level of } \\
\text { significance }\end{array}$ \\
\hline $\begin{array}{l}\text { Triglycerides } \\
(\mathrm{mmol} / \mathrm{L})\end{array}$ & $1.19 \pm 0.31$ & $1.16 \pm 0.36$ & $1.85 \pm 0.13$ & $\begin{array}{l}\mathrm{P}_{\mathrm{I}-\mathrm{III}}<0.001 ; \\
\mathrm{P}_{\mathrm{II}-\mathrm{III}}<0.001\end{array}$ \\
\hline $\begin{array}{l}\text { Cholesterol } \\
(\mathrm{mmol} / \mathrm{L})\end{array}$ & $6.91 \pm 0.89$ & $5.52 \pm 0.36$ & $7.85 \pm 1.34$ & $\begin{array}{l}\mathrm{P}_{\mathrm{I}-\mathrm{II}}<0.01 ; \\
\mathrm{P}_{\mathrm{I}-\mathrm{III}}<0.05 ; \\
\mathrm{P}_{\mathrm{II}-\mathrm{III}}<0.05\end{array}$ \\
\hline Proteins (g/L) & $47.22 \pm 7.24$ & $39.73 \pm 3.03$ & $32.37 \pm 3.94$ & $\begin{array}{l}\mathrm{P}_{\mathrm{I}-\mathrm{II}}<0.05 ; \\
\mathrm{P}_{\mathrm{I}-\mathrm{III}}<0.001 ; \\
\mathrm{P}_{\mathrm{II}-\mathrm{III}}<0.05\end{array}$ \\
\hline LDH (U/L) & $745.27 \pm 10.79$ & $776.09 \pm 11.84$ & $795.20 \pm 10.42$ & $\begin{array}{l}\mathrm{P}_{\mathrm{I}-\mathrm{II}}<0.001 ; \\
\mathrm{P}_{\mathrm{I}-\mathrm{III}}<0.001 ; \\
\mathrm{P}_{\mathrm{II}-\mathrm{III}}<0.001\end{array}$ \\
\hline CK (U/L) & $204.98 \pm 26.78$ & $416.33 \pm 21.68$ & $744.16 \pm 24.70$ & $\begin{array}{l}\mathrm{P}_{\mathrm{I}-\mathrm{II}}<0.01 ; \\
\mathrm{P}_{\mathrm{I}-\mathrm{III}}<0.05 \\
\mathrm{P}_{\mathrm{II}-\mathrm{III}}<0.05\end{array}$ \\
\hline Creatinine $(\mu \mathrm{mol} / \mathrm{L})$ & $34.44 \pm 5.47$ & $32.03 \pm 3.78$ & $29.39 \pm 1.62$ & $\mathrm{P}_{\mathrm{I}-\mathrm{III}}<0.01$ \\
\hline Urea $(\mathrm{mmol} / \mathrm{L})$ & $5.26 \pm 0.87$ & $5.09 \pm 0.86$ & $7.14 \pm 1.01$ & $\begin{array}{l}\mathrm{P}_{\mathrm{I}-\mathrm{III}}<0.001 ; \\
\mathrm{P}_{\mathrm{II}-\mathrm{III}}<0.001\end{array}$ \\
\hline Glucose $(\mathrm{mmol} / \mathrm{L})$ & $13.32 \pm 1.95$ & $16.56 \pm 2.08$ & $17.48 \pm 1.52$ & $\begin{array}{l}\mathrm{P}_{\mathrm{I}-\mathrm{II}}<0.001 ; \\
\mathrm{P}_{\mathrm{I}-\mathrm{III}}<0.001 ;\end{array}$ \\
\hline
\end{tabular}

se) of biochemical parameters are presented in Table 1.

Comparing the quails from the control group and quails treated with $\mathrm{Cr}$ (III) (I vs II) we found that differencies regarding triglyceride, creatinine and urea concentrations were not statistically significant; however all other biochemical parameters showed statistically significant difference. Otherwise, when we analysed differencies between control group and the quails treated with $\mathrm{Cr}(\mathrm{VI})$ (I vs III), we found that all parameters were statistically different. Concentrations of the creatinine and the glucose were not significantly different when we compared quails treated with $\mathrm{Cr}$ (III) and $\mathrm{Cr}$ (VI) (II vs III).

\section{DISCUSSION}

Until today, large number of studies showed that organic chromium in form of chromium picolinate and chromium nicotinate might be used in diets because of their positive influence on reduction of serum glucose and cholesterol concentrations (Yildiz et al., 2004). Data from few animal experiments indicate that with equal solubility, $\mathrm{Cr}(\mathrm{VI})$ compounds are absorbed more readily than $\mathrm{Cr}$ (III) compounds, probably because $\mathrm{Cr}(\mathrm{VI})$ readily penetrates cell membranes. Chromium had no effect in reducing body and liver weights as well as liver and serum cholesterol concentrations.

An explanation for low triglyceride values in all individuals analysed in our 
study, probably lies in the fact that all birds were very young and that they were fed exclusively corn grits which have low content of lipid compounds. Cr(III) did not show high impact on values of triglyceride concentration in serum (Group II) and were not statistically different compared to control group $(\mathrm{P}>0.05)$. After its absorption in the digestive tract, $\mathrm{Cr}$ (III) is "trapped" by the erythrocytes and plasma proteins, so chromium in trivalent form could not convey a significant change in triglyceride serum concentrations (Yildiz et al., 2004). Cr(VI) shows cytotoxic irreversible effects on hepatic tissue, thereby inhibits the synthesis of triglycerides $(\mathrm{Cu}-$ pe \& Donaldson, 1987), which in turn leads to a reduction of triglyceride concentration in serum. Different results in our study may be related to the significantly shorter period of exposure to $\mathrm{Cr}(\mathrm{VI})$, compared to the exposure periods in the cited study. Also, other studies showed that long-term effects of the introduced $\mathrm{Cr}(\mathrm{VI})$ are correlated with the selection of the method for nutrient intake and period of $\mathrm{Cr}(\mathrm{VI})$ elimination from the body (Kitagawa et al., 1988). In this study we used $\mathrm{Cr}(\mathrm{VI})$ oxide that may cause lipid peroxidation, which could explain high level of triglycerides. High urea levels may be consequent to renal disfunction, due to toxic effects of $\mathrm{Cr}(\mathrm{VI})$.

The concentration of cholesterol in Group III was increased $(\mathrm{P}<0.05)$, which is in accordance with previous researches on the effects of $\mathrm{Cr}(\mathrm{VI})$. The reason for higher cholesterol concentration probably lies in the fact that $\mathrm{Cr}(\mathrm{VI})$ has a large oxidation potential. $\mathrm{Cr}(\mathrm{VI})$ is referred as the remarkable pro-oxidant that causes a severe form of cellular stress that subsequently leads to lipid peroxidation of the plasma membrane, which is rich in cholesterol, and hence its significantly increased concentration in serum of individuals in Group III $(\mathrm{P}<0.05)$ (Tonks, 2003).

The activity of lactate dehydrogenase (LDH) was significantly changed in the experimental groups $(\mathrm{P}<0.05)$, especially in quails treated with $\mathrm{Cr}(\mathrm{VI})$. LDH activity in quails treated with $\mathrm{Cr}$ (III) was significantly changed. Interestingly, even in the control group, the activity of LDH was not within the reference range (Sakas, 2002; Scholtz et al., 2009; Sokoll et al., 2015). This increased LDH activity in the control group might be related with growing of quails under stress conditions (cage breeding). A recent study showed that birds in stressful conditions develop more diseases due to cellular stress and lipid peroxidation, accordingly they should be bred with a certain amount of dietary antioxidants (Çiftci et al., 2016). The trend of the increased LDH activity, due to application of chromium (III) chloride, would certainly continue if individuals are exposed to long-term intake of $\mathrm{Cr}$ (III), probably because of the increased accumulation of chromium ions and their irreversible binding to the cellular proteins. LDH activity was also increased in Group III of quails which is a result of the destruction of parenchymal tissues containing $\mathrm{LDH}$ due to extremely toxic effects of $\mathrm{Cr}(\mathrm{VI})$ on cell membranes. Large amounts of LDH enter the circulation as a result of cell death and increased cell membrane permeability (Lewandowski et al., 1986; Binev et al., 2014). Destruction of parenchymal tissues containing LDH (heart, kidney, liver, muscle and other tissues) appears as the consequence of the hydrolytic lysosomal enzymes activity, released due to reduced membrane integrity (Anderson \& Polansky, 1995).

The values of the urea and creatinine serum concentrations were significantly changed only in Group III $(\mathrm{P}<0.05)$; how- 
ever in quails treated with $\mathrm{Cr}$ (III) statistically significant difference was not obtained $(\mathrm{P}>0.05)$. Values of both parameters changed, but remained within the reference range in all three analysed groups (Ukashatu et al., 2014). Cr(III) caused a slight decrease of the urea and creatinine concentrations, which is similar compared to recent studies concerning the effects of $\mathrm{Cr}$ (III) (Shinde \& Goyal, 2003). Urea is found in the plasma of birds in very small quantities, therefore, its role in the assessment of renal efficiency is still questionable. Creatinine is quite "unadequate" parameter for monitoring of renal efficiency, because the birds excrete creatine before its conversion to creatinine (Lewandowski et al., 1986; Lumeij \& Remple, 1991). However, values of these two parameters indicated that $\mathrm{Cr}(\mathrm{VI})$ decreased glomerular filtration and function of renal tubules, especially in Group III.

Serum glucose levels in Groups II and III were significantly different compared to control group. However, many studies showed decrease in serum glucose level due to the effects of $\mathrm{Cr}$ (III) on pancreas chromium-sensitive tissue, which indirectly via LMWCr and GTF modulates glucose metabolism, primarily by enhanced activation of the insulin receptor and stimulation of insulin signalling pathway (Kleefstra et al., 2004). Elevated levels of glucose obtained in Group II resulted from several factors: stress during breeding (Çiftci et al., 2016), insolubility of chromium chloride, and development of oxidative stress or development of endoplasmic reticulum stress (Hu et al., 2011). Effects of $\mathrm{Cr}(\mathrm{VI})$ were arguably stronger and mainly the result of generating numerous biomarkers of oxidative stress.

Higher differencies regarding biochemical parameters were noted between control group and quails treated with
$\mathrm{Cr}(\mathrm{VI})$. In general, $\mathrm{Cr}(\mathrm{VI})$ had toxic effect on quail organism which is manifested with increased values of biochemical parameters except for protein and creatinine concentrations. It could be suggested that $\mathrm{Cr}(\mathrm{VI})$ had harmful influence on functioning and physiological processes of kidneys and muscles. Minor fluctuations regarding concentration or activity of biochemical parameters were observed in quails when they were treated with $\mathrm{Cr}(\mathrm{III})$. It would be necessary to do additional analysis regarding the effect of chromium on the biochemical parameters which will confirm or reject the results obtained in this study. Follow-up period in this study was relatively short to make definitive conclusions regarding the effects of trivalent chromium, therefore future research should examine the long-term effects of trivalent chromium as dietary supplement

\section{REFERENCES}

Anderson, R. \& M. Polansky, 1995. Dietary and metabolite effects on trivalent chromium retention and distribution in rats. Biological Trace Element Research, 50, 97-108.

Binev, R., I. Valchev, K. Stoyanchev, R. Mihaylov \& Y. Nikolov, 2014. Changes in blood enzyme activities after experimental acute intoxication of quails (Coturnix coturnix) with the carbamate insecticide carbofuran. Bulgarian Journal of Veterinary Medicine, 17, 331-337.

Boudjouk, P. \& J. Ho So, 2007. Solvated and unsolvated anhydrous metal chlorides from metal chloride hydrates. Inorganic Synthesis, 29, 108-111.

Cefalu, W.T., F.B. Hu, 2004. Role of chromium in human health and in diabetes. Diabetes Care, 27, 2741-2751.

Çiftci, M., U. G. Şimsek, B. Dalkilic, M. A. Azman, Ö. Yilmaz, S. I. Mutlu, M. Özçelik, Y. Bajkalir, F. Tonbak \& M. Bahşi, 
2016. Effect of dietary orange peel extract on physiological, biochemical, and metabolic responses of Japanese quail reared under low ambient temperature. Turkish Journal of Veterinary and Animal Sciences, 40, 288-279.

Codd, R., C. Dillon, A. Levina \& P. Lay, 2001. Studies on the genotoxicity of chromium: From the test tube to the cell. $\mathrm{Co}$ ordination Chemistry Reviews, 216, 537582.

Cupo, M. \& W. Donaldson, 1987. Chromium and vanadium effects on glucose metabolism and lipid synthesis in the chick. Poultry Science, 66, 120-126.

Dayan, A. \& A. Paine, 2001. Mechanisms of chromium toxicity, carcinogenicity and allerginicity: Review of the literature from 1985 to 2000. Human \& Experimental Toxicology, 20, 439-451.

Hossain, M., S. Barreto \& C. Silva, 1998. Growth preformance and caracass composition of broilers fed supplemental chromium from chromium yeast. Animal Feed Science and Technology, 71, 217-228.

Hu, L., X. Liu, Y. Chevrona, F. Yang, M. Tang, Z. Darzynkiewicz \& W. Dai, 2011. Chromium induces chromosomal instability, which is partly due to deregulation of BubR1 and Emil, two APC/C inhibitors. Cell Cycle, 10, 2373-2379.

Kitagawa, S., H. Seki, F. Kametani \& H. Sakurai, 1988. EPR study on the interaction of hexavalent chromium with glutathione or cysteine: Production of pentavalent chromium and its stability. Inorganica Chimica Acta, 152, 251-255.

Kleefstra, N., H. Bilo, S. Bakker \& S. Houweling, 2004. Chroom en insulineresistentie. Nederlands tijdschrift voor geneeskunde, 148, 217-220.

Króliczewska, B., W. Zawadzki, Z. Dobrzanski, A. Kaczmarek-Oliwa, 2004. Changes in selected serum parameters of broiler chicken fed supplemental chromium. Journal of Animal Physiology and Animal Nutrition, 88, 393-400.
Langard, S., 1990. One hundred years of chromium and cancer: a review of epidemiological evidence and selected case reports. American Journal of Internal Medicine, 17, 189-215.

Lewandowski, A. H., T. W. Campbell \& G. J. Harrison, 1986. Clinical chemistries. In: Clinical Avian Medicine and Surgery. Saunders, Philadelphia, p. 192-200.

Lumeij, J. T., \& J. D. Remple, 1991. Plasma urea, creatinine and uric acid concentrations in relation to feeding in peregrine falcons (Falco peregrinus). Avian Pathology, 20, 79-83.

McDonald, P., R. Edwards \& J. Greenhalgh, 1992. Minerali. U T. Nuove, Nutrizione Animale, fourth edn, Milano, pp. 88-113.

Randall, M. \& G. Bolla, 2008. Raising Japanese quail. Primefacts, 602, pp.1-5.

Sakas, P., 2002. Essentials of Avian Medicine: A Practitioner's Guide, $2^{\text {nd }}$ edn, AAHA Press.

Salnikov, K. \& A. Zhitkovich, 2007. Genetic and epigenetic mechanisms in metal carcinogenesis and cocarcinogenesis: Nickel, arsenic, and chromium. Chemical Research in Toxicology, 21, 28-44.

Scholtz, N., I. Halle, G. Flachowsky \& H. Sauerwein, 2009. Serum chemistry reference values in adult Japanese quails ( $\mathrm{Co}$ turnix coturnix japonica) including sexrelated differences. Poultry science, 88, 1186-1190.

Shati, A.A., 2014. Ameliorative effect of vitamin $\mathrm{E}$ on potassium dichromate-induced hepatotoxicity in rats. Journal of King Saud University, 26, 181-189.

Shinde, U. A. \& R. K. Goyal, 2003. Effect of chromium picolinate on histopathological alterations in STZ and neonatal STZ diabetic rats. Journal of Cellular and Molecular Medicine, 7, 322-329.

Sokoll, R., M. Gesek, M. Ras-Norynska, M. Michalczyk \& S. Koziatek, 2015. Biochemical parameters in Japanese quails Coturnix coturnix japonica infected with 
coccidia and treated with toltrazuril. Polish Journal of Veterinary Sciences, 18, 79-82.

Sugden, K. \& D. Stearns, 1999. The role of chromium (V) in the mechanism of chromate-induced oxidative DNA damage and cancer. Journal of Environmental Pathology, Toxicology and Oncology: Official Organ of the International Society for Environmental Toxicology and Cancer, 19, 215-230.

Thomas, V. \& S. Gropper, 1996. Effect of chromium nicotinic acid supplementation on selected cardiovascular disease risk factors. Biological Trace Element Research, 55, 297-305.

Tonks, N., 2003. PTP1B: From the sidelines to the front lines! FEBS Letters, 546, 140 148.

Ukashatu, S., A. Bello, M. Umaru, J. Onu, A. Shehu, A. Mahmuda \& B. Saidu, 2014. A study of some serum biochemical values of Japanese quails (Coturnix coturnix japonica) fed graded levels of energy diets in Northwestern Nigeria. Scientific Journal of Microbiology, 3, 1-8.

Uyanik, F., A. Atasever, S. Ozdamar, F. Aydin, 2002. Effects of dietary chromium chloride supplementation on performance, some serum parameters, and immune response in broilers. Biological Trace Element Research, 90, 99-115.
Yildiz, A., S. Parlat \& O. Yazgan, 2004. The effects of organic chromium supplementation on production traits and some serum parameters of laying quails. Revue de Médecine Vétérinaire, 155, 642-646.

Zhitkovich, A., 2011. Chromium in drinking water: Sources, metabolism, and cancer risks. Chemical Research in Toxicology, 24, 1617-1629.

Paper received 03.12.2016; accepted for publication 06.02.2017

\section{Correspondence:}

Andi Alijagic

Department of Biology,

Faculty of Science,

University of Sarajevo, 71000 Sarajevo,

Bosnia and Herzegovina

e-mail: andialijagic@gmail.com 